\title{
BIOGEOGRAPHICAL ORIGIN AND VARICELLA RISK IN THE adult imMigration population in Catalonia, Spain (2004-2006)
}

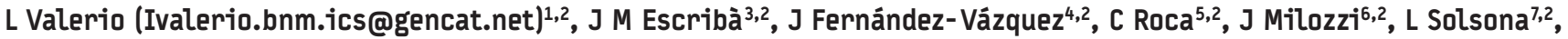 \\ I Molina 8,2 \\ 1.International Health Unit, Barcelonès nord i Maresme Health Region, Catalan Health Institute, Catalonia, Spain \\ 2. Cooperation and International Health Task Group - The Catalan Society of Community and Family Medicine, Catalonia, Spain \\ 3. Cancer Registry of Catalonia Health Department, Government of Catalonia, Catalonia, Spain \\ 4. Besòs primary healthcare centre, Sant Adrià del Besòs, Catalan Health Institute, Catalonia, Spain \\ 5. El Clot primary healthcare centre, Barcelona, Catalan Health Institute, Catalonia, Spain \\ 6. El Fondo primary healthcare centre, Santa Coloma de Gramenet, Catalan Health Institute, Catalonia, Spain \\ 7. La Florida nord primary healthcare centre, L’Hospitalet de Llobregat, Catalan Health Institute, Catalonia, Spain \\ 8. Infectious Diseases Service, Hospital Universitari de la Vall d’Hebron. Barcelona, Catalan Health Institute, Catalonia, Spain
}

This article was published on 17 September 2009

Citation style for this article: Valerio L, Escribà JM, Fernández-Vázquez J, Roca C, Milozzi J, Solsona L, Molina I. Biogeographical origin and varicella risk in the adult immigration population in Catalonia, Spain (2004-2006). Euro Surveill. 2009;14(37):pij=19332. Available online: http://www.eurosurveillance.org/ViewArticle. aspx?ArticleId=19332

Immigrants to the European Union may have a higher susceptibility to varicella-zoster virus primo-infection than the indigenous population. There is no evidence as yet that this is caused by genetic or social factors. Therefore, susceptibility could be due to a lesser transmission of the virus in their ecosystems of origin. A multicentre observational study was performed from July 2004 to June 2006 in four primary healthcare centres in Catalonia, Spain, monitoring varicella incidences and comparing standardised incidence rates and standardised rate ratios among different populations classified according to their biogeographical origin (holarctic, Asian paleotropical, African paleotropical or neotropical). Overall, 516 varicella cases were recorded. The standardised incidence rates per 1,000 inhabitants per year were: holarctic: 2.17 (95\% confidence interval $(\mathrm{Cl})$ : 1.95-2.39); autochthonous 2.26 (95\% Cl: 2.03-2.49); immigrants 3.59 (95\% Cl: 2.92-4.26); neotropical 4.50 (95\% Cl: 3.28-5.71); non-holarctic 5.38 (95\% $\mathrm{Cl}$ : 4.27-6.14); Asian paleotropical 7.03 (95\% Cl: 4.77-9.28); and African paleotropical 7.05 (95\% Cl: 1.12-23.58). The difference to the autochthonous population was greatest in immigrants of neotropical origin (standardised rate ratio $=2.07(95 \% \mathrm{Cl}: 1.61$ 2.64 ) or 4.5 excess cases per 1,000 inhabitants per year) and Asian paleotropical origin (standardised rate ratio $=3.24(95 \% \mathrm{Cl}$ : 2.47-4.11) or 9.6 excess cases per 1,000 inhabitants per year). Biogeographical origin may therefore account for the vulnerability of certain immigrant populations to varicella, in particular those from Asian paleotropical (Indostan and Southest Asia) and neotropical (South America and the Caribbean) ecosystems. Vaccination of immigrants at high risk (fertile women, healthcare workers) could be recommendable.

\section{Introduction}

Varicella is typically a childhood disease ( $87 \%$ of the cases in Spain between 1997 and 2004 were reported in children under the age of 15 years) caused by varicella-zoster virus (VZV)induced primo-infection [1]. Although the disease is usually self- limiting, some cases can be serious, with $2-6 \%$ of them resulting in complications and a hospitalisation rate in the European Union ranging from 1.3 to 4.5 per 100,000 population per year [2]. While the disease is universally distributed, some studies (based on comparison of seroprevalence) point to a greater incidence in cold or temperate northern hemisphere countries - holarctic ecosystem - particularly in winter and spring. There is no explanation to date for the possible lower incidence in Asian, African and South American climates - Asian paleotropical, African paleotropical and neotropical ecosystems, respectively [3]. No hypothesis points to an explanation based on genetics; consequently, it has generally been attributed to a mixture of underreporting and ecological reasons, i.e. VZV would be less transmissible in those ecosystems, although the mechanisms responsible have never been accurately defined [4,5].

However, if these ecological factors do exist, more varicella cases should be seen in the adult immigrant population from tropical-subtropical climates compared to the autochthonous population in Spain who would have a greater degree of immunity from childhood. Furthermore, significant differences should exist between populations of holarctic origin and those of other origin, but not between holarctic immigrants and the autochthonous population.

After centuries of net emigration, Spain has experienced largescale immigration since the year 2000. Currently, the country has the second highest immigration rate of Western Europe just after Cyprus [6]. According to official statistics, 4,144,000 immigrant residents were recorded in Spain in 2005, of whom over 1,500,000 were from Morocco, Ecuador and Romania [6]. Therefore, Spain represents an excellent platform to carry out such a study since the country received a large number of immigrants over a relatively short period of time, which may allow verifying epidemiologically whether or not there was an increase in the incidence of varicella within the immigrant population. Such an analysis of varicella 
incidence should take into account the ecological (biogeographical) and not the geopolitical (according to nationality) origin of the subjects [7-9].

The aim of the present study was to ascertain and compare varicella incidence rates in autochthonous and immigrant populations in Spain according to their biogeographical origin using case registration analysis in primary healthcare centres. It further aimed at discussing the value of the findings with regard to prevention policies to be employed in a country which, in the medium term, is going to receive many more immigrants.

\section{Methods}

This was a multicentre, longitudinal study based on new varicella cases in adults ( $>14$ years, i.e. the unvaccinated population, as vaccination was included in the official vaccination calendar in 2004) from four primary healthcare centres (Centre d'Atenció Primaria, CAP) with a substantial immigrant population, registered between July 2004 and June 2006. Two of these centres are located in Santa Coloma de Gramenet, one in the city of Barcelona and one in Sant Adrià del Besòs. All belong to the Catalan Health Institute (Institut Català de la Salut). The 59 general practitioners (GPS) working in these centres were all blinded to the study question.

The study population consisted of all patients assigned to the four primary healthcare centres. According to data from the Primary Health Informatics System, this comprised 103,902 patients in June 2008. This is a local registration under the primary healthcare system and therefore may reflect more complete and reliable data than census or other general records.

All individuals born in the World Health Oganization (WHO) European Region were defined as autochthonous, and those born outside as immigrants. People born in WHO European Region to immigrant parents were considered to be autochthonous. Classification of the study population according to their ecological zone of origin was based on classical bioregion mapping, which divides the emerged land surfaces into seven zones (Figure) [10]:

- the holarctic region (North America, Europe, Maghreb, Near East, Central Asia, Siberia, China, Korea and Japan),

- the African paleotropical region (sub-Sahara Africa except the western half of South Africa),

- the Asian paleotropical (Indian sub-continent and Southeast Asia),

- the neotropical region (Central America, Caribbean islands and South America),

- and three other regions (South Africa, Antarctica and Oceania) that were excluded since no immigrants from these regions were registered during the study period.

For example, the autochthonous population and immigrants from Morocco or China were considered 'holarctic', while immigrants from Ecuador were classified as 'neotropical'.

A varicella case was defined as a patient registered by the GP as varicella infection in the 'conditions and problems' (diagnosis) section of the computerised clinical records. Cases labelled as 'suspected' or 'probable' were excluded. The variables of age, sex and biogeographical origin were collected.
Age-specific and crude incidence rates were calculated using the population of the four healthcare facilities in the study area as the denominator. Rates were stratified by sex and biogeographical origin, and standardised by the direct method, using the population of Catalonia as a reference according to data available from the 2005 Catalan Statistics Institute [11]. Confidence intervals (CI) for the age-specific and age-standardised rates were calculated using the normal distribution in all groups except for the group of African paleotropical immigrants that contained such a small number of cases that the exact approximation method was used.

Age-standardised rate ratios (ASRR) were defined as the incidence rates of varicella in each group divided by the corresponding incidence rate in the reference group. Cls of ASRR were calculated using the median unbiased estimation method; the Cls which did not include the value ' 1 ' were considered significant $(p<0.05)$ [12]. Subtraction among standardised rate ratios (SRR) represented the excess or deficit of cases per 1,000 inhabitants per year compared to the incidence of the autochthonous population once the differences attributable to population structure had been eliminated.

The EPIDAT 3.0 and R programmes were used for calculating the incidence rates and their respective $\mathrm{Cls}$.

\section{Results}

The study population comprised 103,902 individuals with medical records in their healthcare centres. Of these, 14,387 $(13.8 \%)$ were immigrants. According to the biogeographical origin of those immigrants, $5,470(5.3 \%)$ belonged to the holarctic, $2,806(2.7 \%)$ to the Asian paleotropical, $338(0.3 \%)$ to the African paleotropical, and $5,773(5.6 \%)$ to the neotropical ecosystem.

There were 516 recorded cases of varicella: 296 (57.4\%) men and $220(42.6 \%)$ women with a mean age of 28.1 (standard deviation (SD) 10.5) years. The total incidence of the disease in the adult population, standardised according to age and sex, was 2.44 (95\% Cl: 2.23-2.65) cases per 1,000 inhabitants per year. According to biogeographical origin, the incidence rates standardised per 1,000 persons per year were, in ascending order: holarctic 2.17 (95\% Cl: 1.95-2.39), autochthonous 2.25 (95\% Cl:

\section{F I G U R E}

Biogeographical regions of the world
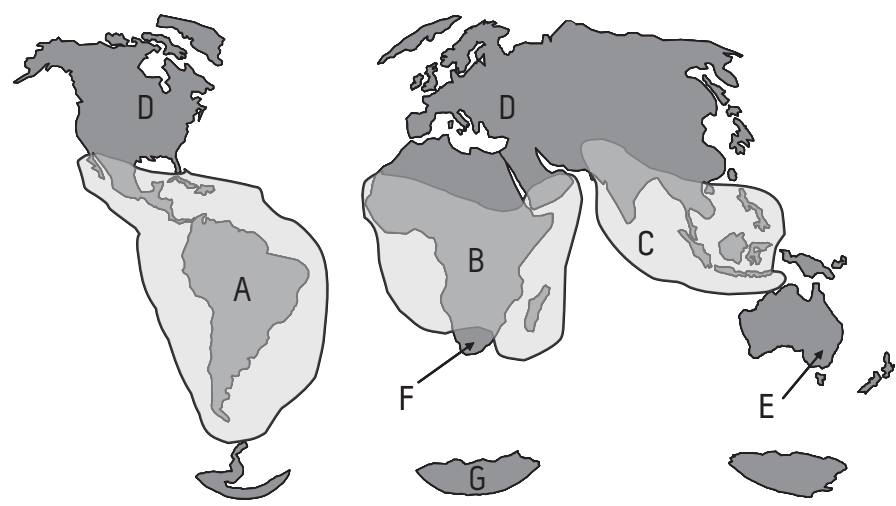

A: Latin America (neotropical); B Africa (African paleotropical); C: Tropical Asia (Asian paleotropical); D: Holoarctic; E: Oceania; F: South Africa; G: Antarctica. 
2.02-2.47), all immigrants 3.59 (95\% Cl: 2.92-4.26), neotropical immigrants $4.50(95 \% \mathrm{Cl}: 3.28-5.91)$, non-holarctic immigrants 5.38 (95\% Cl: 4.27-6.14), Asian paleotropical immigrants 7.03 (95\% Cl: 4.77-9.28) and African paleotropical immigrants 7.05 (95\% Cl: $1.12-23.58)$.
The crude rates obtained during the study period and those standardised for age are presented in Tables 1-3. Crude and agestandardised rate ratios according to biogeographical origin are shown in Table 4. The resulting excess of varicella cases per 1,000 inhabitants is displayed in Table 5.

\section{T A B L E 1}

Crude, age-specific and age-standardised incidence rates of varicella, by geographical origin (autochthonous/immigrants) and sex in the urban health area of Barcelonès nord-Maresme, Catalonia, Spain, 2004-2006

\begin{tabular}{|c|c|c|c|c|c|c|c|c|c|}
\hline \multirow[b]{2}{*}{ Sex and age group } & \multicolumn{3}{|c|}{ Autochtonous } & \multicolumn{3}{|c|}{ Immigrants } & \multicolumn{3}{|c|}{ Total } \\
\hline & $\begin{array}{l}\text { Number of } \\
\text { cases }\end{array}$ & $\begin{array}{c}\text { Study } \\
\text { population }\end{array}$ & Rate (95\% CI) & $\begin{array}{l}\text { Number } \\
\text { of cases }\end{array}$ & $\begin{array}{c}\text { Study } \\
\text { population }\end{array}$ & Rate (95\% CI) & $\begin{array}{c}\text { Number of } \\
\text { cases }\end{array}$ & $\begin{array}{c}\text { Study } \\
\text { population }\end{array}$ & Rate $(95 \%$ CI) \\
\hline \multicolumn{10}{|l|}{ Male } \\
\hline 15-34 years & 147 & 12,768 & $5.75(4.82-6.68)$ & 73 & 4,642 & $7.86(6.6-9.66)$ & 220 & 17,410 & $6.32(5.48-7.15)$ \\
\hline $35+$ years & 62 & 27,887 & $1.11(0.83-1.37)$ & 14 & 3,546 & $1.97(0.94-3.01)$ & 76 & 31,433 & $1.19(0.92-1.46)$ \\
\hline Total / crude rate & 209 & 40,655 & $2.57(2.23-2.93)$ & 87 & 8,188 & $5.32(4.25-6.55)$ & 296 & 48,843 & $3.00(2.65-3.34)$ \\
\hline Age-standardised rate & & & $2.66(1.33-3.04)$ & & & $3.94 \quad(3.03-4.86)$ & & & $2.91(2.58-3.24)$ \\
\hline \multicolumn{10}{|l|}{ Female } \\
\hline $15-34$ years & 134 & 14,422 & $4.64(3.86-5.43)$ & 40 & 3,637 & $5.50(3.79-7.20)$ & 174 & 18,059 & $4.82(4.10-5.54)$ \\
\hline $35+$ years & 36 & 34,438 & $0.52(0.35-0.68)$ & 10 & 2,562 & $1.95(0.74-3.16)$ & 46 & 37,000 & $0.62(0.44-0.80)$ \\
\hline Total / crude rate & 170 & 48,860 & $1.73(1.48-2.01)$ & 50 & 6,199 & $4.04(2.99-5.31)$ & 220 & 55,059 & $1,99(1.73-2.26)$ \\
\hline Age-standardised rate & & & $1.90(1.61-2.18)$ & & & $3.14(2.15-4.12)$ & & & $2.02(1.75-2.29)$ \\
\hline \multicolumn{10}{|l|}{ Total } \\
\hline $15-34$ years & 281 & 27,190 & $5.16(4.56-5.77)$ & 113 & 8,279 & $6.82(5.65-8.33)$ & 394 & 35,469 & $5.55(5.01-6.11)$ \\
\hline $35+$ years & 98 & 62,325 & $0.78(0.62-0.93)$ & 24 & 6,108 & $1.96(1.18-2.75)$ & 122 & 68,433 & $0.89(073-1.1)$ \\
\hline Total / crude rate & 379 & 89,515 & $2.11(1.90-2.34)$ & 137 & 14,387 & $4.76(3.99-5.63)$ & 516 & 103,902 & $2.48(2.26-270)$ \\
\hline Age-standardised rate & & & $2.26(2.03-2.49)$ & & & $3.59(2.92-4.26)$ & & & $2.45(2.24-2.67)$ \\
\hline
\end{tabular}

Rates are per 1,000 inhabitants per year. The age-standardised rates were calculated using the age distribution of the 2005 Catalan population census and confidence intervals (CI) rates of $95 \%$.

\section{T A B L E 2}

Crude, age-specific and age-standardised incidence rates of varicella by biogeographical origin (holarctic/non-holarctic) and sex in the urban health area of Barcelonès nord-Maresme, Catalonia, Spain, 2004-2006

\begin{tabular}{|c|c|c|c|c|c|c|c|c|c|}
\hline \multirow[b]{2}{*}{ Sex and age groups } & \multicolumn{3}{|c|}{ Holarctic } & \multicolumn{3}{|c|}{ Non-holarctic } & \multicolumn{3}{|c|}{ Total } \\
\hline & $\begin{array}{l}\text { Number } \\
\text { of cases }\end{array}$ & $\begin{array}{c}\text { Study } \\
\text { population }\end{array}$ & Rate (95\% CI) & $\begin{array}{c}\text { Number } \\
\text { of } \\
\text { cases }\end{array}$ & $\begin{array}{c}\text { Study } \\
\text { population }\end{array}$ & Rate (95\% CI) & $\begin{array}{c}\text { Number of } \\
\text { cases }\end{array}$ & Study population & Rate $(95 \%$ CI $)$ \\
\hline \multicolumn{10}{|l|}{ Male } \\
\hline $15-34$ years & 152 & 13,950 & $5.45(4.58-6.31)$ & 68 & 3,079 & $11.04(8.42-13.66)$ & 220 & 17,029 & $6.46(5.63-7.37)$ \\
\hline $35+$ years & 62 & 29,391 & $1.05(0.79-1.32)$ & 14 & 1,865 & $3.75(1.78-5.72)$ & 76 & 31,256 & $1.21(0.96-1.52)$ \\
\hline Total / crude rate & 214 & 43,341 & $2.47(2.15-2.82)$ & 82 & 4,944 & $8.29(6.59-10.29)$ & 296 & 48,285 & $3.07(2.72-3.43)$ \\
\hline Age-standardised rate & & & $2.52(2.19-2.86)$ & & & $6.19(4.61-7.77)$ & & & $2.97(2.63-3.31)$ \\
\hline \multicolumn{10}{|l|}{ Female } \\
\hline $15-34$ years & 139 & 15,300 & $4.54(3.78-5.30)$ & 35 & 2,504 & $6.99(4.67-9.31)$ & 174 & 17,804 & $4.88(4.17-5.67)$ \\
\hline $35+$ years & 37 & 35,534 & $0.52(0.36-0.69)$ & 9 & 1,469 & $3.65(1.06-5.06)$ & 46 & 37,003 & $0.62(0.46-0.88)$ \\
\hline Total / crude rate & 176 & 50,834 & $1.73(1.48-4.00)$ & 44 & 3,973 & $6.54(4.03-7.43)$ & 220 & 54,807 & $2.00(1.75-2.29)$ \\
\hline Age-standardised rate & & & $1.86(1.59-2.14)$ & & & $4.37(2.83-5.92)$ & & & $2.05(1.28-2.32)$ \\
\hline \multicolumn{10}{|l|}{ Total } \\
\hline $15-34$ years & 291 & 29,250 & $4.97(4.41-5.54)$ & 103 & 5,583 & $9.22(7.44-11.00)$ & 394 & 34,833 & $5.65(5.10-6.23)$ \\
\hline $35+$ years & 99 & 64,925 & $0.76(0.61-0.91)$ & 23 & 3,334 & $3.45(2.04-4.86)$ & 122 & 68,259 & $0.89(0.74-1.07)$ \\
\hline Total / crude rate & 390 & 94,175 & $2.07(1.87-2.28)$ & 126 & 8,917 & $7.07(5.88-8.41)$ & 516 & 103,902 & $2.50(2.28-2.70)$ \\
\hline Age-standardised rate & & & $2.17(1.95-2.39)$ & & & $5.38(4.27-6.14)$ & & & $2.49(2.27-2.70)$ \\
\hline
\end{tabular}

Rates are per 1,000 inhabitants per year. Age-standardised rates were calculated using the age distribution of the 2005 Catalan population census and confidence intervals (CI) rates of $95 \%$. 
In summary, significant differences in the varicella incidence rates were found between the autochthonous and immigrant populations. These differences were accentuated when the group of holarctic populations was compared with the group of non-holarctic populations, and when the holarctic population was compared to the neotropical and, particularly, Asian paleotropical populations.
In contrast, no statistically significant differences were observed when the autochthonous and holarctic populations were compared.

\section{Discussion and conclusions}

The possible epidemiological changes in the number of varicella infections due to the influx of immigrants had already been noted

TA B L E 3

Crude, age-specific and age-standardised incidence rates of varicella by biogeographical origin and sex in the urban health area of Barcelonès nord-Maresme, Catalonia, Spain, 2004-2006

\begin{tabular}{|c|c|c|c|c|c|c|c|c|c|c|c|c|}
\hline \multirow[b]{2}{*}{$\begin{array}{l}\text { Sex and age } \\
\text { groups }\end{array}$} & \multicolumn{3}{|c|}{ Holarctic } & \multicolumn{3}{|c|}{ Asian paleotropical } & \multicolumn{3}{|c|}{ African paleotropical } & \multicolumn{3}{|c|}{ Neotropical } \\
\hline & \begin{tabular}{|l|} 
Number \\
of cases
\end{tabular} & $\begin{array}{c}\text { Study } \\
\text { population }\end{array}$ & Rate $(95 \%$ CI $)$ & $\begin{array}{l}\text { Number } \\
\text { of cases }\end{array}$ & $\begin{array}{c}\text { Study } \\
\text { population }\end{array}$ & CI) Rate $(95 \%$ & \begin{tabular}{|l|} 
Number \\
of cases
\end{tabular} & $\begin{array}{c}\text { Study } \\
\text { population }\end{array}$ & Rate $(95 \% \text { CI })^{1}$ & $\begin{array}{c}\text { Number } \\
\text { of } \\
\text { cases }\end{array}$ & $\begin{array}{c}\text { Study } \\
\text { population }\end{array}$ & Rate (95\% CI) \\
\hline \multicolumn{13}{|l|}{ Male } \\
\hline 15-34 years & 152 & 13,950 & $\begin{array}{c}5.45(4.58- \\
6.31) \\
\end{array}$ & 27 & 1,418 & $9.52(6.28-13.58)$ & 1 & 156 & $3.21(0.8-17.86)$ & 40 & 1,505 & $\begin{array}{c}13.29(9.49- \\
18.09) \\
\end{array}$ \\
\hline $35+$ years & 62 & 29,391 & $\begin{array}{c}1.05(0.79- \\
1.32) \\
\end{array}$ & 9 & 922 & $4.88(2.23-9.25)$ & 0 & 90 & 0.00 & 5 & 853 & $\begin{array}{c}2.93(0.95- \\
6.84) \\
\end{array}$ \\
\hline Total / crude rate & 214 & 43,341 & $\begin{array}{c}2.47(2.15- \\
2.82) \\
\end{array}$ & 36 & 2,340 & $7.69(5.39-10.65)$ & 1 & 246 & $2.04(0.05-11.33)$ & 45 & 2,358 & $\begin{array}{c}9.53(6.96- \\
12.77) \\
\end{array}$ \\
\hline $\begin{array}{l}\text { Age-standardised } \\
\text { rate }\end{array}$ & & & $\begin{array}{c}2.52(2.19- \\
2.86)\end{array}$ & & & $6.43(3.99-8.87)$ & & & $1.07(0.003-1.47)$ & & & $\begin{array}{l}6.40(4.20- \\
8.59)\end{array}$ \\
\hline \multicolumn{13}{|l|}{ Female } \\
\hline 15-34 years & 139 & 15,300 & $\begin{array}{c}4.54(3.78- \\
5.30) \\
\end{array}$ & 11 & 253 & $\begin{array}{l}21.74(10.85- \\
38.89)\end{array}$ & 0 & 77 & 0.00 & 24 & 2,174 & $\begin{array}{c}6.52(3.53- \\
8.21)\end{array}$ \\
\hline $35+$ years & 37 & 35,534 & $\begin{array}{c}0.52(0.36- \\
0.69) \\
\end{array}$ & 2 & 213 & $4.69(0.57-16.96)$ & 2 & 15 & $\begin{array}{c}66.66(8.08- \\
240.82)\end{array}$ & 5 & 1,241 & $\begin{array}{c}2.02(0.65- \\
4.70)\end{array}$ \\
\hline Total / crude rate & 176 & 50,834 & $\begin{array}{c}1.73(1.48- \\
4.00)\end{array}$ & 13 & 466 & $13.95(7.43-23.85)$ & 2 & 92 & $\begin{array}{c}10.87(1.31 .- \\
39.26)\end{array}$ & 29 & 3,415 & $\begin{array}{c}4.24(2.84- \\
6.10) \\
\end{array}$ \\
\hline $\begin{array}{l}\text { Age-standardised } \\
\text { rate }\end{array}$ & & & $\begin{array}{c}1.86(1.59- \\
2.14) \\
\end{array}$ & & & $10.40(4.30-16.5)$ & & & $\begin{array}{c}44.36(5.37- \\
160.22) \\
\end{array}$ & & & $\begin{array}{c}3.19(1.80- \\
4.57)\end{array}$ \\
\hline \multicolumn{13}{|l|}{ Total } \\
\hline 15-34 years & 291 & 29,250 & $\begin{array}{c}4.97(4.41- \\
5.54) \\
\end{array}$ & 38 & 1,671 & $11.37(8.04-15.60)$ & 1 & 233 & $1.14(0.06-11.95)$ & 64 & 3,679 & $\begin{array}{c}8.7(6.70- \\
9.81) \\
\end{array}$ \\
\hline $35+$ years & 99 & 64,925 & $\begin{array}{c}0.76(0.61- \\
0.91) \\
\end{array}$ & 11 & 1,135 & $4.84(2.42-8.67)$ & 2 & 105 & $9.52(1.15-34.40)$ & 10 & 2,094 & $\begin{array}{c}2.39(1.14- \\
4.39)\end{array}$ \\
\hline Total / crude rate & 390 & 94,175 & $\begin{array}{c}2.07(1.87- \\
2.28)\end{array}$ & 49 & 2,806 & $8.73(6.46-11.54)$ & 3 & 338 & $4.44(0.91-12.97)$ & 74 & 5,773 & $\begin{array}{l}6.41(5.04- \\
8.05) \\
\end{array}$ \\
\hline $\begin{array}{l}\text { Age-standardised } \\
\text { rate }\end{array}$ & & & $\begin{array}{l}2.17(1.95- \\
2.39)\end{array}$ & & & $7.03(4.77-9.28)$ & & & $7.05(1.12-23.58)$ & & & $\begin{array}{l}4.50(3.28- \\
5.71)\end{array}$ \\
\hline
\end{tabular}

Rates are per 1,000 inhabitants per year. Age-standardised rates were calculated using the age distribution of the 2005 Catalan population census and confidence intervals (CI) rates of $95 \%$.

1 Because of the small number of cases for the African paleotropical group, 95\% CIs were calculated using exact methods.

T A B L E 4

Crude rate ratio (CRR) and age-standardised rate ratio (ASRR) for varicella by geographical and biogeographical origin and sex in the urban health area of Barcelonès nord-Maresme, Catalonia, Spain, 2004-2006

\begin{tabular}{|l|c|c|c|c|c|c|}
\hline \multicolumn{1}{|c|}{ Sex } & \multicolumn{2}{c|}{ Male } & \multicolumn{2}{c|}{ Female } & \multicolumn{2}{c|}{ Total } \\
\hline $\begin{array}{l}\text { Geographical and biogeographical } \\
\text { origin }\end{array}$ & CRR (95\% CI) & ASRR (95\% CI) & CRR (95\% CI) & ASRR (95\% CI) & CRR (95\% CI) & ASRR (95\% CI) \\
\hline Autochtonous & 1 (reference) & 1 (reference) & 1 (reference) & 1 (reference) & 1 (reference) & 1 (reference) \\
\hline Immigrants & $2.09(1.61-2.67)$ & $1.48(1.14-1.87)$ & $2.33(1.69-3.18)$ & $1.65(1.19-2.24)$ & $2.27(1.86-2.75)$ & $1.60(1.25-1.96)$ \\
\hline Holarctic & 1 (reference) & 1 (reference) & 1 (reference) & 1 (reference) & 1 (reference) & 1 (reference) \\
\hline Asian paleotropical & $3.12(2.16-4.39)$ & $2.55(1.79-3.60)$ & $8.15(4.40-13.75)$ & $5.57(3.21-9.51)$ & $4.22(3.10-5.63)$ & $3.24(2.47-4.11)$ \\
\hline African paleotropical & $0.94(0.04-4.10)$ & $0.42(0.01-3.89)$ & $6.76(1.05-21.02)$ & $23.76(5.94-69.2)$ & $2.25(0.54-5.88)$ & $3.25(0.8-5.84)$ \\
\hline Neotropical & $3.87(2.77-5.29)$ & $2.53(1.83-3.44)$ & $2.45(1.63-3.59)$ & $1.71(1.26-2.03)$ & $3.10(2.40-3.95)$ & $2.07(1.61-2.64)$ \\
\hline Non-holarctic 1 & $3.36(2.59-4.32)$ & $2.45(1.88-3.11)$ & $3.20(2.28-4.42)$ & $2.34(1.68-3.24)$ & $3.41(2.78-4.16)$ & $2.48(2.03-3.02)$ \\
\hline
\end{tabular}


in the mid-twentieth century. Causes of the changes have been assumed to be: the presence of adult immigrants susceptible to the disease, and the introduction of new strains of VZV $[13,14]$. Those studies were based on seroprevalence - generally on samples from blood banks - and on genetic analyses of the isolated viruses. Subsequently, a substantial series of articles was published that warned of epidemic outbreaks in immigrant communities and their immunological vulnerability. Articles cited in PubMed between 1997 and 2007 defined as risk communities immigrants from the Indian subcontinent [15-17], South America [18,19], Africa [20] or a combination of two of them [21]. Only one study (in Oceania, a non-holarctic ecosystem) did not report differences between immigrants and autochthonous individuals [22]. Although the evidence provided in these studies is based solely on the greater seronegativity in immigrants, they clearly suggest that this vulnerability is due to factors related to the transmissibility of VZV in their respective ecosystems of origin. No hypothesis regarding genetic or cultural causes was raised.

The present study is consistent with the approaches above in that it confirms - from a purely epidemiological point of view higher incidence rates in individuals from ecological environments that are very different from the European or holarctic region. Furthermore, the fact that no differences were found between the autochthonous European population and immigrants of other holarctic biogeographical origin (i.e. people from the Maghreb, Near East, central Asia, China and North America) is not only in line with the ecological hypothesis but an argument against a role of genetic factors. One of the limitations of this study is the lack of a comparative analysis of varicella incidence rates in children and further research in that direction should be encouraged. One would expect the differences between the groups to disappear when comparing rates in children of autochthonous families and children of immigrant families born in Europe.

Two further limitations of the study should be noted: firstly, the possible bias due to different social situations in the study groups (e.g. housing conditions or the proportion of women of childbearing age) that could facilitate the spread of the infection in a given group, and secondly, the strictly epidemiological approach of the study which did not take into account seroprevalence. Also, immigrants from certain areas, particularly Africa, could be underregistred in Spain and therefore cause a bias. Nevertheless, the local demographic records used are considered trustworthy and, thus, any bias was likely small.

T A B L E 5

Excess of cases per 1,000 inhabitants by biogeographical origin with respect to the autochthonous population, Catalonia, Spain, 2004-2006

\begin{tabular}{|l|c|}
\hline Biogeographical origin & Excess of cases per 1,000 inhabitants \\
\hline Autochthonous & 0 (reference) \\
\hline African paleotropical & -1.25 \\
\hline Holarctic & 0.16 \\
\hline All immigrants & $2.68^{\star}$ \\
\hline Neotropical & $4.5^{\star}$ \\
\hline Non-holarctic & $6.26^{\star}$ \\
\hline Asian paleotropical & $9.56^{\star}$ \\
\hline
\end{tabular}

The observed differences were most marked in male individuals under the age of 35 years. However, this may be a coincidental observation and due to the limited number of cases in people over 35 years of age. Nevertheless, the differences between the sexes could be due to possible inequalities in the access to healthcare for female immigrants who may be discriminated against. Other epidemiology-based studies also raised this possibility $[23,24]$.

Similarly, the African paleotropical population was not strongly represented which makes it difficult to draw definitive conclusions. The incidence $\mathrm{Cl}$ in this group compared with the autochthonous and holarctic populations was not significant for the men, but significant for the women. Only one earlier study has described an African paleotropical population with a seroprevalence of antibodies against VZV that was significantly lower than that in the European population [18], but these were immigrants from East Africa (refugees from Somalia) who are very rare in Spain and therefore do not allow a comparison with our study. From our data, we can only conclude that significant differences do not appear to exist between the sub-Saharan African population from West Africa, the largest in Spain and the local autochthonous population.

The vulnerability to varicella in immigrants from the holarctic ecosystem (i.e. China or Turkey) appeared to follow a similar age pattern as in the autochthonous population. Both groups had fewer cases in adults than in children. This probably reflects a higher VZV transmission in childhood and the development of permanent immunity after infection. In contrast, immigrants from the neotropical and, particularly, Asian paleotropical ecosystems show an epidemiological pattern typical of an adult population with greater susceptibility to the disease [25].

All varicella cases were identified according to the diagnosis made by 59 GPs. Considering their experience, this purely clinical ascertainment, albeit subjective, is likely to be reliable. There is no reason to suppose that the diagnosis should be more or less accurate for immigrants than for autochthonous groups.

Preventive measures for these populations with lower immunity should be considered. Although determining the cost-effectiveness of a vaccination against VZV was not the aim of this study, it should be emphasised that some institutions do recommend (United States Army) [26] or consider it (Catalan Autonomous Government) [27]. Studies that supported the inclusion of the chickenpox vaccine in the childhood vaccination schedule defined an incidence threshold for cost-effectiveness at much lower rates than those found in vulnerable immigrant communities [28]. Selective vaccination of the young adult population from South America or the Indian subcontinent without a history of chickenpox in childhood would very likely be cost-effective as far as direct and particularly indirect expenses (loss of productivity) are concerned [29]. Within these populations, two high-risk groups can be defined: women of childbearing age, in order to protect them against varicella infection during pregnancy and to ensure the transplacental diffusion of maternal antibodies to the foetus $[30,31]$, and immigrant healthcare personnel, who are at a high risk of acquiring the infection [32]. An additional argument in favour of selective vaccination is the possibility that immigrants might introduce holarctic strains of VZV to their countries of origin when visiting their families. Such transcontinental spreads caused the measles epidemic in Ecuador in 2008 [33] and, probably, the outbreak of German measles in Brazil in 2007 [34]. 
Those high-risk target populations could be vaccinated without the need for a serological study [35]. In countries with limited resources such as Spain (where patients must purchase a vaccine at prices ranging from EUR 45 to 60 ), a possible strategy aimed at increasing social acceptance would be to test healthy immigrant women for varicella antibodies (usually accounting for less than EUR 15) in primary care screening programmes, which usually include the routine test for German measles [36].

Varicella vaccination would surely be indicated for adult immigrants living together with child index cases, since epidemic outbreaks with a high attack rate within families have been described [37]. Thereby, cases of chickenpox in pregnant women and neonates could be avoided, the two groups in whom severe cases occur most frequently. This would require an improved coordination of GPs and epidemiologists, a faster response to an increase in the number of cases, and easier access to vaccination without costs for the individuals [38].

In conclusion, certain immigrant populations, particularly from neotropical and Asian paleotropical biogeographic origin, present a higher incidence rate of varicella than autochthonous inhabitants of Spain and other holarctic populations. The reasons for this elevated vulnerability probably depend on ecological factors that limit transmissibility of the virus in their ecosystems of origin. Thus, the implementation of preventive measures using biogeographical origin as a criterion could be effective. Analysis of the influence of different biogeographical origins on the epidemiology of infectious microorganisms should be completed with further studies.

\section{References}

1. Instituto de Salud Carlos III. National Epidemiology Centre. Epidemiological Surveillance Service. Situación de la varicela en España. [Varicella situation in Spain]. National Epidemiology Centre. 2006. [Spanish]. Available from: http://www.isciii.es/htdocs/centros/epidemiologia/pdf/InformevaricelaCNE.pdf

2. Bonnani P, Breuer J, Gershon A, Gershon M, Hryniewicz W, Papaevangelou V, et al. Varicella vaccination in Europe - taking the practical approach. BMC Med. 2009; 7:26.

3. Lee BW. Review of varicella zoster seroepidemiology in India and Southeast Asia. Trop Med Int Health. 1998;3(11):886-90.

4. Weller TH. Varicella: historical perspective and clinical overview. J Infect Dis. 1996;174 Suppl 3:S306-9.

5. Kjersem H, Jepsen S. Varicella among immigrants from the tropics, a health problem. Scand J Soc Med. 1990;18(3):171-4

6. National Institute for Statistics. Statistical exploitation of the municipal census until 1 January 2006. [Explotación estadística de los datos del padrón a 01 de enero de 2006]. National Institute for Statistics. 1 March 2007. [Spanish]. Available from: http://www.ine.es/prensa/np447.pdf

7. Ramette A, Tiedje JM. Biogeography: an emerging cornerstone for understanding prokaryotic diversity, ecology, and evolution. Microb Ecol. 2007;53(2):197-207.

8. Green JL, Bohannan BJ, Whitaker RJ. Microbial biogeography: from taxonomy to traits. Science. 2008;320(5879):1039-43.

9. Horner-Devine MC, Carney KM, Bohannan BJ. An ecological perspective on bacterial biodiversity. Proc Biol Sci. 2004;271(1535):113-22.

10. Brown JH, Gupta VK, Li BL, Milne BT, Restrepo C, West GB. The fractal nature of nature: power laws, ecological complexity and biodiversity. Philos Trans R Soc Lond B Biol Sci. 2002;357(1421):619-26.

11. Statistical Institute of Catalonia. 2005 Census population data. Statistical Institute of Catalonia. [Spanish]. [Accessed 15 September 2009]. Available from: http://www.idescat.cat/territ/BasicTerr?TC=8\&V3=863\&V4=435\&ALLINFO $=$ TRUE\&PARENT $=1 \& V 0=3 \& V 1=0 \& C T X=B \& V N=3 \& V O K=$ Confirmar

12. Rothman KJ, Greenland S. Modern Epidemiology, Second edition. Philadelphia: Lippincot- Raven Publishers. U.S.A.;1998:353-5.

13. Hawrami K, Hart IJ, Pereira F, Argent S, Bannister B, Bovill B, et al. Molecular epidemiology of varicella-zoster virus in East London, England, between 1971 to 1995. J Clin Microbiol. 1997;35(11):2807-9.
14. Ross LF, Lantos JD. Immunisation against chickenpox. BMJ. 1995;310(6971):873.

15. Gabutti G, Fedele A, Aprile V, Guido M, Lopalco P. Immigration flows and new epidemiological evidence in Southern Italy. Vaccine. 2003;21(5-6):399-400.

16. Uduman SA, Tahira AM, Al-Wash R, Usmani MA, Bener A. Varicella susceptibility among children and healthy adults in the United Arab Emirates. East Mediterr Health J. 2001;7(4-5):604-8.

17. Kubeyinje EP, Belagavi CS, Desai S. Ethnic differences in the severity of varicella in adults in northern Saudi Arabia. East Afr Med J. 1997;74(11):727-8.

18. Barnett ED, Christiansen D, Figueira M. Seroprevalence of measles, rubella and varicella in refugees. Clin Infect Dis. 2002;35(4):403-8.

19. Goldberg JM, Ziel HK, Burchette R. Evaluation of varicella immune status in an obstetric population in relation to place of birth. Am J Perinatol. 2002;19(7):387-94.

20. Nysse LJ, Pinsky NA, Bratberg JP, Babar-Weber AY, Samuel TT, Krych EH, et al. Seroprevalence of antibody to varicella among Somali refugees. Mayo Clin Proc. 2007;82(2):175-80.

21. Avrahami-Heller Y, Cohen D, Orr N, Slepon R, Ashkenazi I, Danon YL. Immunity to varicella zoster virus in young israelí adults. Isr Med Assoc J. 2000;2(3):196-9.

22. O'Grady KA, Merianos A, Patel M, Gilbert L. High seroprevalence of antibodies to varicella zoster in adult women in a tropical climate. Trop Med Int Health. 2000;5(10):732-6.

23. Valerio L, Milozzi J, Figueredo A, Reina MD, Martínez-Cuevas 0, Pérez-Quỉez 0. [Prevalence of diabetes mellitus in young Asian Indian immigrants in Santa Coloma de Gramenet (Spain)]. Med Clin (Barc). 2006;126(2):53-6. [Spanish].

24. Faura T, García F, Isla P, López C, Robau M, Moreno A, et al. Health problems and social vulnerability in immigrants admitted for an infectious disease: a case-control study. Rev Clin Esp. 2007;207(5):234-9.

25. Liyanage NP, Fernando S, Malavige GN, Mallikahewa R, Sivayogan S, Jiffry MT, et al. Seroprevalence of varicella zoster infections in Colombo district, Sri Lanka. Indian J Med Sci. 2007;61(3):128-34.

26. Struewing JP, Hyams KC, Tueller JE, Gray GC. The risk of measles, mumps and varicella among young adults: a survey of US Navy and Marine Corps recruits. AM J Public Health. 1993;83(12):1717-20.

27. Plans P, Costa J, Espuñes J, Plasència A, Salleras L. Prevalence of varicellazoster antibodies in pregnant women in Catalonia (Spain). Rationale for varicella vaccination of women of childbearing age. BJOG. 2007;114(9):1122-7.

28. Lenne X, Díez-Domingo J, Gil A, Ridao M, Lluch JA, Dervaux B. Economic evaluation of varicella vaccination in Spain: results from a dynamic model. Vaccine. 2006;24(47-48):6980-9.

29. Díez-Domingo J, Gil A, San-Martín M, González A, Esteban J, Baldó JM, et al. Seroprevalence of varicella among children and adolescents in Valencia, Spain. Reliability of the parent's reported history and the medical file for identification of potential candidates for vaccination. Hum Vaccin. 2005;1(5): 204-6.

30. Pinot de Moira A, Edmunds WJ, Breuer J. The cost-effectiveness of antenatal varicella screening with post-partum vaccination of susceptibles. Vaccine. 2006;24(9):1298-307.

31. Smith WJ, Jackson LA, Watts DH, Koepsell TD. Prevention of chickenpox in reproductive-age women: cost-effectiveness of routine prenatal screening with post-partum vaccination of susceptibles. Obstet Gynecol. 1998;92(4 Pt 1):535-45.

32. Hastie IR. Varicella-zoster virus affecting immigrant nurses. Lancet. 1980;2(8186):154-5.

33. Ecuador Ministry of Public Health. Informe de investigación de la epidemia de sarampión. [Measles Outbreak Investigation Report ]. Available from: www. msp.gov.ec/index.php?option=com_content\&task=view\&id=223\&Itemid=1

34. Pan American Health Organization. Elimination of rubella and of congenital rubella syndrome. Progress report. Pan American Health Organization. 2007. [Spanish]. Available from: http://www.paho.org/Spanish/AD/FCH/IM/ InformeProgreso_RubeolSRC_2007.pdf

35. Wagenpfeil S, Neiss A, Banz K, Wutzler P. Empirical data on the varicella situation in Germany for vaccination decisions. Clin Microbiol Infect. 2004;10(5):425-30.

36. Bernaola E, Jiménez F, Baca M. Criterios de inclusión de vacunas en el calendario de la Asociación Española de Pediatría. [Criteria for bacines inclusion in the Schedule of the Spanish Association of Pediatrics]. An Pediatr. 2008;68(1):58-62.

37. Macartney K, McIntyre P. Vaccines for post-exposure prophylaxis against varicella (chickenpox) in children and adults. Cochrane Database Syst Rev. 2008;(3):CD0019833.

38. Centers for Disease Control and Prevention (CDC). Public Health Response to Varicella Outbreaks--United States, 2003-2004. MMRW Morb Mortal Wkly Rep. 2006;55(36):993-5. 